\title{
Capital Structure and Financial Performance of the Quoted Firms in the Nigerian Stock Exchange: An Econometric Approach
}

\author{
Aderemi Timothy Ayomitunde ${ }^{1 *}$, Sejoro Mauton Zannu ${ }^{2}$, Alaka Adedayo ${ }^{3}$ \\ ${ }^{1}$ Department of Economics, Olabisi Onabanjo University, Ago Iwoye, Ogun State, Nigeria \\ ${ }^{2,3}$ Departnent of Banking and Finance, Yaba College of Technology, Lagos, Nigeria
}

\begin{abstract}
$\begin{array}{ll}\text { DOI: } 10.36348 / \text { sjbms.2019.v04i11.003 } & \text { | Received: 08.11.2019| Accepted: } 15.11 .2019 \text { | Published: } 24.11 .2019\end{array}$
*Corresponding author: Aderemi Timothy Ayomitunde

Abstract

The aim of this paper is to examine the relationship between capital structure and financial performance of firms listed in the Nigerian stock exchange between 2012 and 2017. Data were extracted from 40 companies out of 169 companies which are listed on the Nigerian Stock Exchange as at 2018. Consequently, ordinary pooled least square was adopted to analyze the objective of study. The principal findings that originate from this study is that capital structure has a negative impact on return on equity and return on asset of the firm listed on the Nigerian stock exchange. In view of the above important findings that originated in this work, it is paramount that the following recommendations are made for the investors and the policy makers in Nigeria that debt capital is not a profitable means of financing investment projects in firms listed in the Nigerian stock exchange. However, all hands must be on deck by the Nigerian policy makers to embark on policy measure to reduce double digit interest rate in the financial sector in order to ensure self-liquidating debt capital in the listed firms in the Nigerian stock exchange.
\end{abstract}

Keywords: Capital Structure, ROA; ROE; Nigerian Stock Exchange.

Copyright @ 2019: This is an open-access article distributed under the terms of the Creative Commons Attribution license which permits unrestricted use, distribution, and reproduction in any medium for non-commercial use (NonCommercial, or CC-BY-NC) provided the original author and source are credited.

JEL Classification: M14

\section{INTRODUCTION}

Capital structure has been conceptualized as the different ways to finance a company`s investment projects. In the context of capital structure, a company could finance its investment projects through only equity, only debt or a mixture of the two [1]. Capital structure decision depicts one of the most vital strategies that determines the profitability of an enterprise because a successful selection and optimal use of capital represent the most principal element of the firms' financial strategy.

In the recent times, capital structure has attracted attention of researchers because its positive multiplier effects have been attributed to proper and efficient practice in the administration of business entities which indirectly leads to the reduction in the incidence of corporate failures. Correct capital structure decision plays a paramount role in the running of an organization, deviation from this has the tendency to cost the company a lot of risks which could reduce the performance of the company. The risks that accompany the activities of the firm are shared by the firm's shareholders in the same way they share the business profit. It is instructive to state that the value of a company is a function of the streams of expected earnings and the rate at which the earnings is discounted. The capital structure decision of a firm possesses a high tendency to impact on its value by either altering cost of capital or the expected earnings.

However, the decision of choosing a suitable financing structure in an organization is motivated by series of internal and external factors, which may include the nature of industry in terms of competition, growth, stability of sales, profit and the assets value in one hand and sensitivity of creditors due to high debt on a company on the other hand. Therefore, the underlining problems of capital structure emanate from the correct determination of the quantum of each source 
of finance that will bring about optimum return to the organization with little or no risks [2, 3]. In view of the above, it is apparent that an attempt to establish that the exact effect of capital structure on financial performance of the listed companies in the Nigerian stock exchange has brought about divided opinions in the literature. Gambo et al., [4] discovered a significant positive relationship between long term, short-term liability and firm financial performance. Meanwhile, Abosede and Kajola [5] submitted that a negative and significant relationship exist between the financial performance of firms and capital structure in Nigeria. In addition, the following studies also show conflicting results [6-8]. Due to the inconclusiveness nature of literature regarding this subject matter it is pertinent to re-examine the relationship between capital structure and finance performance of Nigerian listed companies in the recent time. Therefore, this study will move the frontiers of knowledge in this regards by examining the impact of capital structure on financial performance of listed companies in Nigeria. The uniqueness of this study also lies in the utilization of econometric technique in addressing its objective in which several studies in Nigeria failed to adopt.

\section{LITERATURE REVIEW}

The section critically reviewed past studies on nexus between capital structure and firm performance

Ajibola and Qudus [9] used a panel analysis to verify the relationship between capital structure and financial performance of manufacturing firms listed in Nigerian stock exchange between 2005 and 2014. It was established from the paper that capital structure in terms of long term debt ratio, total debt ratio has a positive significant relationship with return on equity, whereas reverse was the case on return on asset. Nwachukwu and Akpeghughu [10] adopted regression analysis to evaluate a relationship between capital structure and firms performance in the Nigerian banking industries. The study discovered a positive and significant relationship between equity capital and return on investment. Meanwhile, a negative and significant relationship existed between debt capital and return on investment. Onaolapo and Kajola [11] critically examined the nexus between capital structure and performance of non-financial firms in Nigeria between 2001 and 2007 with reference to agency cost theory. The study provided an evidence to support agency cost theory by concluding that capital structure has a significant negative impact on both return on asset and return on equity of the firms. Similarly, Adesina, Nwidobie and Adesina [12] analyzed the link between the post consolidation capital structure and financial performance of banks quoted on the Nigerian stock exchange with the application of ordinary least square. It was discovered from the study that capital structure and financial performance of these quoted banks have a significant and positive relationship. Toraman et al., [13] evaluated how capital structure decisions affected the profitability of manufacturing sector in Turkey from 2005 to 2011. The results from the regression analysis showed that short term debt to total assets and long term liabilities to total assets have a negative impact on return on asset. But, a direct relationship existed between operating income, financial expenditures and profitability. Oke and Afolabi [14] estimated the linkage between the capital structure and industrial performance in Nigeria of five quoted firms. The authors argued that a positive relationship existed between equity, debt equity finances and performance. However, reverse was the case debt financing and performance. Salim and Yadav [15] employed a panel data analysis to explore the relationship between capital structure and firms financial performance from 1995 to 2011. The authors concluded that there was an existence of a positive relationship between growth and performance for all the sectors. The results from Tobin's Q also indicated that there was a significant direct relationship between short term debt and long term debt in one hand, total debt has a significant inverse relationship with the firms' performance under study.

In the same vein, Javed and Akhtar [16] employed correlation analysis to investigate how capital structure affected financial performance between 2004 and 2008. The result from the paper showed a positive linkage between the variables of interest.

Raluca [17] analyzed impact of capital structure on corporate performance of companies on Romania stock exchange between 2010 and 2012 with the aid of regression analysis. It was discovered from the study that the degree of capital structure was strongly influenced the firm's performance in the country.

However, the reviewed of the empirical literature so far established that the studies on capital structure and financial performance in Nigeria are yet to reach a consensus about the nature of the relationship that exists between these variables. Hence, the relevance of this study.

\section{METHODOLOGY}

This paper utilizes secondary data from 2012 to 2017 for its analysis. Data of various variables were extracted from the annual financial reports of companies listed in the Nigeria stock. The target population in this study is 169 companies which are listed on the Nigerian Stock Exchange as at 2018. Meanwhile, a total of 40 listed firms operating in high profile industries were purposively chosen for this study. This accounts for about $23.7 \%$ of the targeted population in this work. The selected sample size is large enough to make empirical generalization because Uwuigbe [18] advocated for a minimum of $5 \%$ of a defined population as an appropriate sample size in making generalization. It is instructive to state that the 
purposive sampling technique adopted in this study was largely due to the sub sectors representation and the availability of the annual reports of the companies. The following are the list of the selected firms for the study; Abbey Mortgage Bank, Access Bank, AG Leventis, AXA Mansard, Berger Paint, C and I Leasing, Cap Plc, Caverton, Champion Breweries, Consolidated Hallmark Insurance, Consolidated Reinsurance Plc, Dangote Cement, Diamond Bank, Ecobank, FCMB, Fidelity
Bank Plc, First Bank, Forte Oil, GTBank, Guiness, Honeywell, International Breweries Plc, Jaiz Bank Plc, Julius berger, Lafarge Africa Plc, Nascon, Nestle, Nigerian Brew. Plc, Oando Plc, Portland Paint \& Products Nig., PZ, Royal Exchange Plc, StanbicIBTC Bank Plc, Sterling Bank Plc, Transcorp, UBA, Unilever Nigeria Plc, Union Bank Plc, Unity Kapital Assurance $\mathrm{Plc}$ and WAPIC Insurance Plc.

Model Specification

$$
\begin{aligned}
& \mathrm{ROE}_{\mathrm{it}}=\mathrm{F}(\mathrm{TDEt}, \mathrm{LDEt} \text {, SDEt }) \\
& \text { ROA }_{\text {it }}=\mathrm{F}(\text { TDEt, LDEt, SDEt }) \\
& \mathrm{ROE}_{\mathrm{it}}=\beta_{\mathrm{o}}+\beta_{1} \mathrm{TDE}_{\mathrm{it}}+\beta_{2} \mathrm{LDE}_{\mathrm{it}}+\beta_{3} \mathrm{SDE}_{\mathrm{it}}+U_{t} \\
& \mathrm{ROA}_{\mathrm{it}}=\beta_{\mathrm{o}}+\beta_{1} \mathrm{TDE}_{\mathrm{it}}+\beta_{2} \mathrm{LDE}_{\mathrm{it}}+\beta_{3} \mathrm{SDE}_{\mathrm{it}}+U_{t}
\end{aligned}
$$

Where:

ROE and ROA represent Return on Equity and Return on Asset for the firms and is used to measure the firm financial performance.

TDE represents total debt to equity, LDE represents long term debt to equity and SDE represents short term debt to equity.
$U_{t}$, the error term which account for other possible factors that could influence ROEit that are not captured in the model. $\mathrm{i}=1 \ldots 40, \mathrm{t}=$ 2012

The a priori expectation is such that $\beta_{1}, \beta_{2}$ and $\beta_{3}>0$.

\section{RESULTS AND DISCUSSION}

Table-1: Descriptive Statistics of Annual Data Series

\begin{tabular}{|l|l|l|l|l|l|}
\hline Descriptive Statistics & ROA & ROE & TDE & LDE & SDE \\
\hline Mean & 0.058759 & 0.146603 & 2.735999 & 0.567689 & $3.00 \mathrm{E}+08$ \\
\hline Median & 0.028582 & 0.123568 & 1.390513 & 0.310579 & 1.5946648 \\
\hline Maximum & 0.792676 & 2.068606 & 11.37994 & 7.163827 & $4.56 \mathrm{E}+09$ \\
\hline Minimum & -0.206767 & -4.041013 & -2.969212 & -0.018366 & 825.2900 \\
\hline Std. Deviation & 0.116609 & 0.398130 & 2.846437 & 0.984042 & $6.85 \mathrm{E}+08$ \\
\hline Skewness & 3.093159 & -4.012764 & 1.048209 & 4.204578 & 2.986945 \\
\hline Kurtosis & 1.906167 & 5.957162 & 3.197096 & 2.743701 & 1.797521 \\
\hline Jargue-Bera & 2604.642 & 29757.85 & 44.33819 & 4605.281 & 1316.787 \\
\hline Probability & 0.000000 & 0.000000 & 0.000000 & 0.000000 & 0.000000 \\
\hline Sum & 14.10207 & 35.18462 & 656.6398 & 136.2455 & $7.20 \mathrm{E}+10$ \\
\hline Sum. Sq. Deviation & 3.249850 & 37.88325 & 1936.427 & 231.4329 & $1.12 \mathrm{E}+20$ \\
\hline Observation & 240 & 240 & 240 & 240 & 240 \\
\hline
\end{tabular}

Source: Authors` Computation (2019)

The table above presents the descriptive statistics of the data employed in this study. This is very crucial because it provides a useful information about the distribution of the data series. It could be observed from the table above that the values of mean and median of all the variables are almost identical. This implies that the distribution of the data series is nearly symmetrical. A distribution of data series is perfectly symmetrical when the values of mean, mode and median of such data are [19]. Also, the normal distribution of the data series could be confirmed from the value of Kurtosis which is not significantly different from 3 .

Table-2: Impact of Capital Structure on Return on Asset Method: Ordinary Least Square (OLS)

\begin{tabular}{|l|l|l|l|l|l|l|l|}
\hline Dependent Variable & \multicolumn{2}{|l}{ ROA } & \multicolumn{2}{l|}{ ROE } \\
\hline Variable & Coefficient & t-stat & P-value & Variable & Coefficient & t-stat & P-value \\
\hline SDE & $-1.39 \mathrm{E}-11^{* * *}$ & 1.26 & 0.2059 & SDE & $-3.03 \mathrm{E}-11$ & 0.84 & 0.4017 \\
\hline LDE & $-0.018317^{* *}$ & 2.42 & 0.0160 & LDE & $-0.139456^{*}$ & 5.61 & 0.0000 \\
\hline TDE & $-0.008000^{* *}$ & 2.99 & 0.0031 & TDE & $-0.016748^{* * *}$ & 1.90 & 0.0580 \\
\hline C & $0.095218^{*}$ & 8.90 & 0.0000 & C & $0.280683^{*}$ & 7.98 & 0.0000 \\
\hline R-Squared & 0.84675 & & & R-Squared & 0.150473 & & \\
\hline Adjusted R-Squared & 0.73040 & & & Adjusted R-Squared & 0.139674 & & \\
\hline
\end{tabular}

Source: Author`s Computation (2019) ***Significant at 10\%, **Significant at 5\%, *Significant at 1\%, 
The estimated results of the regression analysis were shown in Table-2. All the explanatory variables did not have the expected sign. However, the explanatory variables in the model jointly explained about $84 \%$ of the systematic variations in the dependent variable, return on asset leaving $16 \%$ unexplained as result of random chance. This connotes that this model is comparatively good for the analysis. Meanwhile, when the loss in the degree of freedom was adjusted, the explanatory power reduces to $73 \%$.

Moreover, the estimated results show that short term debt to equity, long term debt to equity and total debt to equity have a negative relationship with return on asset which is significant at $10 \%$ and $5 \%$ level of significance respectively. This implies that the impact of capital structure in terms of debt financing is retarding the return on asset of the listed firms in the Nigerian stock exchange.

In the same vein, the relationship between all the variables used to proxy capital structure and return on equity is negative and significant except short term debt to equity. In view of the above, it could be deduced that debt capital has led to a negative financial performance of the listed companies in the Nigerian stock exchange. The reason for this negative performance might be connected to expensive cost of capital in the form of double digits interest rate in Nigeria. It is worth of note that the findings in this study are in line with the submission of Ishaya and Abuduljeleel [20], Nwangi, Makau and Kosimbei [21] in related studies in Nigeria and Kenya simultaneously.

\section{CONCLUSION AND RECOMMENDATION}

In this paper an attempt has been made to empirically examine the relationship between capital structure and financial performance of 40 listed firms in the Nigerian stock exchange between 2012 and 2017. The study hereby establishes the following among others that capital structure has a negative impact on return on equity and return on asset of the firm listed on the Nigerian stock exchange. In view of the above important findings that originated in this work, it is paramount that the following recommendations are made for the investors and the policy makers in Nigeria that debt capital is not a profitable means of financing investment projects in firms listed in the Nigerian stock exchange. However, all hands must be on deck by the Nigerian policy makers to embark on policy measure to reduce double digit interest rate in the financial sector in order to ensure self-liquidating debt in the listed firms in the Nigerian stock exchange.

\section{REFERENCE}

1. Dare, F. D., \& Sola, O. (2010). Capital Structure and Corporate Performance in Nigeria Petroleum Industry: Panel Data Analysis. Journal of Mathematics and Statistics, 6(2): 168-173.
2. Akintoye, I. R. (2016). Investment Decisions in the 21st Century. Unique Educational Publishers, Lagos, Nigeria

3. Dada, A. O., \& Ghazali, Z. B. (2016). The Impact of Capital Structure on Firm Performance: Empirical Evidence from Nigeria. Journal of Economics and Finance, 7(4), 23-30.

4. Gambo Boukary, A., Diaw, A., \& Wünscher, T. (2016). Factors affecting rural households' resilience to food insecurity in Niger. Sustainability, 8(3), 181

5. Abosede Adebiyi, J., \& Kajola Sunday, O. (2011). Ownership structure and firm performance: evidence from Nigerian listed companies. Corporate Ownership \& Control, 8(4), 391-402.

6. Isaac, L. (2014). Corporate capital structure and firm's market value in Nigeria. Research Journal of Finance and Accounting, 5(12), 16-31.

7. Akinyomi, O. J., \& Olagunju, A. (2013). Determinants of capital structure in Nigeria. International Journal of Innovation and Applied Studies, 3(4), 999-1005.

8. Salawu, R. O., \& Awolowo, O. (2009). The effect of capital structure on profitability: An empirical analysis of listed firms in Nigeria. The International Journal of Business and Finance Research, 3(2), 121-129.

9. Ajibola, A., Wisdom, O., \& Qudus, O. L. (2018). Capital structure and financial performance of listed manufacturing firms in Nigeria.

10. Uchechukwu, N., \& Kingsley, A. M. (2016). Effect of Capital Structure on Firm Performance (A Study of Selected Quoted Banks in Nigerian Stock Exchange). The International Journal of Business \& Management, 4(4), 114-122.

11. Onaolapo, A. A., \& Kajola, S. O. (2010). Capital structure and firm performance: evidence from Nigeria. European Journal of Economics, Finance and Administrative Sciences, 25(1), 70-82.

12. Adesina, J. B., Nwidobie, B. M., \& Adesina, O. O. (2015). Capital structure and financial performance in Nigeria. International Journal of Business and Social Research, 5(2), 21-31.

13. Toraman, C., Kihc, Y., \& Reis, S. G. (2013, May). The effects of capital structure decisions on firm performance: Evidence from Turkey. In International Conference on Economic and Social Studies, 1(1), 10-11.

14. Oke, O. S. \& Afolabi, B. (2011). Capital Structure and Industrial Performance in Nigeria. International Business and Management, 2(1), 100-106.

15. Salim, M., \& Yadav, R. (2012). Capital structure and firm profitability: Evidence form Malaysian listed companies. Procedia Social and Behavioural Sciences, 65: 156-66.

16. Javed, B., \& Akhtar, S. (2012). Interrelationships between capital structure and financial performance, firm size and growth: comparison of 
industrial sector in KSE. European Journal of Business and Management, 15 (4), 148, 157.

17. Moscu, R. G. (2014). Capital structure and corporate performance of Romanian listed companies. International Journal of Academic Research in Accounting, Finance and Management Sciences, 4(1), 287-292.

18. Uwuigbe, U. (2014). Corporate governance and capital structure: evidence from listed firms in Nigeria Stock Exchange. The Journal of Accounting and Management, 4(1).
19. Karmel P. H., \& Polasek M, (1980). Applied statistics for economists.

20. La Baco, S., Kahirun, K., Hasani, U. O., \& Jalil, A. (2017). Analisis Ketersediaan Dan Kebutuhan Air Di Daerah Aliran Sungai Roraya Provinsi Sulawesi Tenggara. Jurnal Ecogreen, 3(1), 1-8.

21. Mwangi, L. W., Makau, M. S., \& Kosimbei, G. (2014). Relationship between capital structure and performance of non-financial companies listed in the Nairobi Securities Exchange, Kenya. Global Journal of Contemporary Research in Accounting, Auditing and Business Ethics, 1(2), 72-90. 